\title{
The Ambivalence of the Sense of Touch in Early Modern Prints
}

SHARON ASSAF

Les conséquences de l'indulgence envers les plaisirs du toucher étaient le sujet d'un débat au cours du XVI $I^{e}$ siècle. Alors qu'il était généralement admis que s'adonner aux plaisirs du toucher pouvait conduire aux dangers de succomber à plusieurs autres vices, entre autres le plus traitre des péchés mortels, Luxuria, d'autres conceptions contemporaines mettaient en relation le sens du toucher avec la vertu. Un nouveau regard sur le développement du thème iconographique du sens du toucher qui a émergé au début du XVI siècle, en particulier dans le traité didactique moralisateur Stultiferae naves de Jodicus Badius Ascensius (publié à Lyon en 1500), ainsi que dans les séries (datant des environs de 1544) de Georg Pencz - le Kleinmeister de Nuremberg -, révèle que ces ouvrages exprimaient cette ambivalence à l'égard du sens du toucher.

t was a widespread view in the sixteenth century that giving in to the pleas-
ures of touch led to the further danger of succumbing to any number of
vices, among them the most treacherous deadly sin of Luxuria. However,
alongside the familiar association of the sense of touch with the vice of lech-
ery, there existed other notions linking the sense of touch with virtue. The
consequence of man's indulgence in the pleasures of the sense of touch was a
debated point in the sixteenth century. Recent scholarship evaluating the rep-
resentation of the sense of touch in early modern culture has focused on the
changing and even opposing notions of this sense in a variety of scientific,
literary, theatrical, and visual forms. ${ }^{1}$ Missing from this appraisal, however,
is a study of the iconographic tradition of the sense of touch that was being
developed during this period. ${ }^{2}$ The reason for this omission appears to be the
general belief among scholars that the early works that set out to typify the
visual iconography of the five senses in general, and of touch in particular, are Renaissance and Reformation / Renaissance et Réforme, XXIX, 1 (2005) /75 
not representative of the range of interpretation that existed in other cultural manifestations of the period and that the descriptions and depictions of the sense of touch in these early graphic works showed only the sense's relation to wantonness, lust, and seduction. As Elizabeth Harvey recently noted, "the sense of touch perhaps most frequently evokes the erotic and seductive, and early modern depictions of the Five Senses sometimes portray Touch through lascivious or pornographic scenes."3

This study advocates a new look at the earliest serial treatment of the five senses in the graphic arts, which begins at the dawn of the sixteenth century. The didactic treatise Stultiferae naves by the northern humanist Jodicus Badius Ascensius, published in Lyons in $1500,{ }^{4}$ and the first print series devoted to the theme of the five senses by the Nuremberg kleinmeister Georg Pencz, dated to around $1544,{ }^{5}$ reveal nuanced approaches to the notion of the efficacy of the sense of touch where the dangers of this most sensual sense are balanced by subtle hints of how to counter its sway. The creators of these formative iconographic representations position their contentions about the benefits and dangers of indulging in the sense of touch within a clear moralizing context that reflects the social, cultural, and religious climate of the times. Badius, the anonymous illustrator of the Stultiferae naves, and Georg Pencz each seek to transmit to their respective audiences-through their artful use of learned prose, clever verse, or sophisticated imagery - a relevant message about how one might negotiate the lure of the tactile sense. ${ }^{6}$ Their verbal and visual depictions draw attention to the power of the hand as the organ of touch that can be used in the pursuit of vice or virtue. ${ }^{7}$ We will see that these early modern works continue a long tradition of moralizing texts and images that presented the hand as the organ of touch which, if left unchecked by reason, could lead man to pursue pleasures that endanger his temporal and spiritual wellbeing, but that if commanded by reason and used for virtuous deeds, would ensure his comfort on earth and his salvation in heaven.

While recent scholarly interest in Badius's Stultiferae naves has focused primarily on the author's and the anonymous illustrator's original contribution to the motif of the fool, as well as on the misogynist message, ${ }^{8}$ Badius's treatise may be seen as the opening text in a centuries-long debate about the efficacy of the senses that engaged moralists, natural scientists, and artists. ${ }^{9}$ Both Badius' and Pencz's works were created in the print medium, equivalent to mass production in our time. They were intended for the growing numbers of reading/viewing urban elite, and therefore serve as a kind of cultural barometer for both the perception and treatment of the theme of the senses among the sophisticated early modern burghers in the first decades of the sixteenth century. They present the contemporary conventional wisdom on 
this topic, as the text and images were intended to appeal to an audience that could negotiate the visual and verbal cues. Such an audience would have found in these works not only aesthetic appeal and intellectual interest, but also didactic lessons intended to strengthen moral fiber.

Badius' Stuliferae naves, an early printed book combining prose, verse, and woodcut illustrations, is the first text of the sixteenth century devoted to a moralizing appraisal of man's five senses. Originally intended as an addendum to the Latin edition of Sebastian Brant's best-selling Das Narrenschiff, Badius continues Brant's innovative motif of the fool in order to deliver a sober message about the dangers of giving in to the pleasures of the senses at the expense of reason. He likely intended his text primarily for a male readership that could negotiate the Latin text, while the finely executed woodcuts that embellish each chapter would have helped the female viewers to grasp the meaning of prose and verse that would probably have been read aloud to them by their husbands or fathers.

In the chapter devoted to the sense of touch in Stultiferae naves, Badius rails against capitulation to the foolish seductions of Venus. He provides a concise account of the great heroes of history who brought disaster upon not only themselves but also their communities by succumbing to the pleasures of the flesh:

\footnotetext{
The war of Troy in fact came about because of Venus who suggested the rape of Helen and Troy was destroyed, and because of intoxication, the Lapiths, people of Thessaly were destroyed by the Centaurs. The other examples are too well known I think to need to be cited and it is not necessary that I develop the point against the abuse of Venus and what folly leads to forbidden touch, seeing that this is the unique subject about which one reads and sees. In this boat one finds the sons of God who have sinned with the daughters of men: the sons of Israel who went with the daughters of Moab, David, his sons, the Sodomites and their neighbors. Moreover, if one were to gather together all the dirty bodies of this sense in one boat, the sea would not be big enough to hold them all. ${ }^{10}$
}

The illustration accompanying this chapter shows a ship filled with male and female fools, in contemporary clothing, engaging in a variety of sexual dalliances (fig. 1). In his concluding plea to the reader, however, Badius offers tales of exemplary behaviour among historical figures who were able to conquer their sinful, sensual impulses and use their senses toward good ends, in the hope that this will help the contemporary reader to escape from the ships of fools that are powered by seductions of the senses. ${ }^{11}$ Badius, penning his treatise at the dawn of the new century, leaves his readers little room for error in the use of their external faculties. 
In Pencz's unique visualization, created about 40 years later (fig. 2), the learned peintre-graveur creates an image that is intentionally ambivalent, allowing for the viewer to uncover varied and even opposing meanings within the imagery. In so doing, Pencz allows his audience to replicate the actual process of sense perception as it was understood at the time. The copper-plate engraving was aimed at the educated male viewer, ${ }^{12}$ who would have been familiar both with the reigning notion of how man's external senses functioned, and with the role of the internal senses in interpreting information and stimuli gathered by the external sense organs. He would also have been aware of the role that judgment, thought at the time to be situated in the sensus communis, played in interpreting these stimuli to his benefit or detriment. ${ }^{13}$ The image of touch, in particular, underscores the ongoing debate regarding the pivotal role of this sense in following the path of virtue or vice. The ambivalent meaning of the senses in the guise of nude female personifications - simultaneously seducing the viewer and presenting him with a moral lesson about each sense-would not have been lost on the sophisticated male viewer in mid-sixteenth century Nuremberg. ${ }^{14}$

In the opening lines of his chapter on touch, Badius restates commonly held notions about this sense: that it is the last in the hierarchical ranking of the senses, that it is common to all living beings, and that it is spread throughout the body. Yet, at the centre of the woodcut illustration to Badius's text, and in Pencz's depiction of the personification of touch, is the hand. In each, the hand is perceived as the organ of touch, but in the former it is depicted as an offending appendage, whereas in the latter it is shown engaged in a worthy activity. In the woodcut, the hands of the four male and three female fools push, pull, grab, grope, prod, stroke, and fondle one another in a display of lustful indiscretion. What appears at first as a tangle of fingers and fists is in fact a carefully arranged play of hands across the middle of the composition. The gestures of the two couples on either end of the skiff mirror each other and hyphenate the circular arrangement of the hands of the three fools in the middle. Pencz has also placed the single pair of hands of the personification of touch at the centre of his composition, but here the fingers of Touch gracefully pull at the threads on a small ribbon loom. It would seem that in these two renderings of the sense of touch, the question of whether man's tactile sense leads him to virtuous pursuits or to vice was dependant upon how the organ of touch was used.

The iconography of the sense of touch has been related to images of luxuria, lust, sexual abandonment, and the wantonness of women, leading to the overall view in modern scholarship that in the sixteenth century this sense was visualized as dangerous and corrupting. ${ }^{15}$ These suppositions de- 
rive from the numerous associations in both literary and visual sources, from Antiquity to the early modern period, that related the sense of touch both to the experience of sexual arousal and to the idea that the sense of touch, alone among the senses, was not localized in one organ, but rather was spread throughout the body. ${ }^{16}$

Louise Vinge, in her study of the literary tradition of the five senses, traces the view of the sense of touch as it relates to sensual pleasure back to Xenophon's fable of Hercules at the crossroads, where he recounts in Memorabilia the female temptress' attempt to entice Hercules to choose the pleasant rather than the virtuous path of life. ${ }^{17}$ The temptress lures Hercules with the experience of pleasure through the senses. The sense of touch described as, "what tender love can give you most joy, what bed the softest slumbers," suggests the sexual pleasures that only this sense can provide. ${ }^{18}$ Vinge also points out that the first century Alexandrian philosopher Philo Judaeus adapted Xenophon's tale of Hercules at the crossroads, but changed the two women exemplifying Virtue and Vice into two wives battling for their husband's love, in order to explain in a more concrete manner the battle going on in man's soul between vice and virtue. ${ }^{19}$ Philo pits pleasure, that is the indulgence of the senses, against reason. Each wife presents her grounds for preference, but Philo makes it clear that the benefits of the virtuous wife far outweigh those of her rival even though the attainment of her gifts may be more difficult as they require physical labour. ${ }^{20}$

The wife who represents the life of pleasure tempts her husband with joys that can be known through the senses, beginning with sight and ending with touch: “...you will find colors all and sundry, sweet modulations of melodious sounds, costly kinds of food and drink, abundant varieties of delicious perfumes, amours without ceasing, frolics unregulated, chamberings unrestricted...."21 These last promises of pleasure awaiting the one who abandons control of his reason to the senses clearly associates the sense of touch with sexual intercourse. Philo even offers three variations of this pleasure. We should, however, also note that among the first promises offered by the pleasure-seeking wife are, "freedom from the sense of restraint, from the fear of punishment, from the stress of business, from the discipline of labor."22 Freedom from the discipline of labour suggests that the hands play a special role for man as a balance between pleasure and toil, and ultimately between vice and virtue. Freeing the hands from the stresses and demands of business and labour enables their use in indulgence of the senses. If man yields to his senses then all moderation is lost; the virtues that ensure man's comfort in the material world-including his private role within his family and his public position within his community, which he is able to maintain 
through restraint, business, and labour-are forgotten in the world of sensual pleasure. Indeed the second wife, who enjoins her husband to favour her and pursue a life of virtue, explicitly states the virtues of labour: "But in my store there is one thing which seems especially to involve hardship and discomfort...practice makes it sweet and reflection shows it to be profitable. This thing is toil, the first and greatest of blessings, the enemy of ease, waging war to the death against pleasure. For in very truth, God has appointed toil as the beginning of all goodness and true worth to men and without it you shall find nothing excellent takes shape amongst mortal men."23

Early Christian theologians, in their moralizing approach to the senses, also associated touch with the dangers of sexual pleasure. In his discussion of the senses in the Divine Institutions, the fourth-century Christian apologist Lactantius, discusses only sexual pleasure under the heading of touch and categorizes pleasure as the weapon of the devil. ${ }^{24}$ Augustine assigns to touch the dangerous power of sexual temptation in his Confessions. ${ }^{25}$

In the fifteenth and sixteenth centuries, the association of lust with the sense of touch was almost a commonplace. Badius' discussion of the dangers of succumbing to the temptations of touch relates this sense to one of the greatest episodes of sexual indiscretion and misconduct recorded in ancient history:

\footnotetext{
As Pliny said, we sin with our senses innumerable ways and with each of our members. Moreover, the same Pliny (Historia naturalis 10.72) also said: “All animals enjoy coupling but for man it is never enough. Messalina the wife of Emperor Claudius was judged worthy of the palm of victory after she won a contest with a prostitute for bedding twenty-five men in one night." On this subject Juvenal wrote, in his Satire (6), "She was tired but far from satisfied." This because the desire towards passionate love is so violent in a man that poets represent adulterers even among the gods, according to Juvenal, the first among sins is lust. ${ }^{26}$
}

The anonymous illustrator indicates in a concise manner the connection between the sense of touch and the sin of lust by depicting the ship of touch flying under the flag of Luxuria symbolized by the goat (fig. 1). ${ }^{27}$ As we noted earlier, the illustrator also visually implicates the hand as the sense organ that perpetrates these sinful acts of lovemaking. He makes clear also how abandoning one's reason to the folly of touch will lead to one's impoverishment, as the male fool sitting at the back of the boat seems unaware that his purse is being emptied by his female companion. ${ }^{28}$

Though Badius presents a damning appraisal of mankind's insatiable lust that is aroused, temporarily gratified, but never sated by the sense of touch, he does offer in one of his final pleas to his readers some words of 
advice on how to avoid the treacherous pitfalls of the enticements of the senses:

With regard to human nature, it is that which gives us permission to hide the glue of seductions caused by objects charming to our sight, the penetrating insinuations caused by the pertinent caresses of hearing, the tension of the desire provoked by the temptations of smell, the alluring viands and delicacies of taste and the voluptuous titillations of caressing embraces, finally so that we not enter the trap, and not be broken by them. But for this the essential is to run from idleness and inaction, it is the work, the anxiety, the concern, the economy, the sobriety, the simplicity of dress which is not dirty but simple, and the other things of this nature according to Juvenal, Satire VI, which show the distancing of luxury and the safeguarding of chastity, in these words: "In days of old, the wives of Latium were kept chas[t]e by their humble fortunes. It was toil and brief slumbers that kept vice from polluting their modest homes; hands chafed and hardened by Tuscan fleeces, Hannibal nearing the city, and husbands standing to arms at the Colline tower. We are now suffering the calamities of long peace. Luxury, more deadly than any foe, has laid her hand upon us, and avenges a conquered world. Since the day when Roman poverty perished, no deed of crime or lust has been wanting to us.” These are his words. ${ }^{29}$

Badius warns his readers against giving in to bad impulses that are aroused through the senses, and he explicitly advises them to run from the consequences of idleness and inactivity, which will result from surrender. Especially interesting is his reliance on the passage from Juvenal, which stresses the dangers awaiting a society at peace, where a life of luxury becomes the deadly foe. Though he does not use the term, it would seem that the malady that infects the society-which Badius, by using the quotation from Juvenal, draws reference with his own-is otium. In his study of the changing meaning of this word from Antiquity to the early modern period, Brian Vickers notes that though modern philologists have translated it as "leisure," the celebration of the contemplative life that is lived far from the stresses of business and politics, in Antiquity and the Renaissance the term otium was an ambivalent concept, which, while occasionally interpreted as leisure, could also connote the idleness, inactivity, lust, and wantonness that overcome one who leads the life of leisure. ${ }^{30}$

As Vickers points out, Ovid drew a direct connection between Venus, the goddess of love and lovemaking, and the consequences of otium, and warned lovers to avoid it at all costs. ${ }^{31}$ The sense of touch, as the sense most closely associated with lovemaking, is thus incidentally responsible for the dangerous effects of this idle leisure. Ovid offers the listless-in-love advice to counteract the effects of otium: to keep busy and active, to work. Juvenal similarly noted that, for the ancient Roman men and women, "It was toil and brief slumbers that kept vice from polluting their modest homes; hands 
chafed and hardened by Tuscan fleeces, Hannibal nearing the city, and husbands standing to arms at the Colline tower." Badius must have intended for his readership to draw the appropriate moral lesson from Juvenal's Satire: in order to avoid the detrimental effects of yielding to the pleasures of one's senses, which is caused by idleness that in turn leads to insidious love, one must pursue the active life and toil, which will bring the greater virtues of sobriety, moderation, and economy. For Badius' sophisticated urbanite audience that included burghers, merchants, and craftsmen, pursuit of the active life could have meant any type of task from the execution of civic duties to manual labour.

The Church fathers had long associated idleness with lust. While the ancient Romans considered otium to be a moral vice, the Church equated it with the mortal sin of acedia, slothfulness: the source of all the vices. Christian theologians and preachers cautioned that the idle hand was a sign of sloth. ${ }^{32}$ This notion was visualized towards the end of the sixteenth century in a print by Philips Galle that was part of the series, The Idler's Punishment. This print shows the idler refusing to work during harvest time, illustrating Proverbs 20:4, “The sluggard will not plow by reason of the cold.” Lying in the left foreground, the idler has tucked his left hand inside his shirt where it lies close to his breast, a direct illustration of the description of the idler in Proverbs 26:15: "The slothful hideth his hand in his bosom."33 Galle's print series shows that the slothful will never share in the bounties of this world.

The illustrator of the Stultiferae naves implicated the hand as the implement of lust in his depiction of the folly of the sense of touch, but Badius made clear that the hand could also be the implement of redemption. He advocates work as the cure for the idleness, inactivity, and debauchery infecting a society that knows too much of luxury. Juvenal's descriptions of the women's hands that were worn by carding the fleece, and of the men who took up arms in defense of their city, would have been understood by the contemporary reader as advocating work that encompasses both manual labour and civic responsibility, a common call among preachers and moralizers at the time. Thus, the hand was not just censured; it was also praised.

Praise of the hand, the organ of touch, can be traced back to Aristotle, who had equated touch with perception. As he states in De anima: "We may assume that we actually have perception of everything which is apprehended by touch (for by touch we perceive all those things which are qualities of the tangible object)." 34 In De partibus animalium, Aristotle discusses the human hand, the most important human facilitator of touch. Although he disagrees with Anaxagoras, who considered the hand the means of man's intelligence, Aristotle praises this appendage for other reasons: "now the 
hand would appear to be not one single instrument but many, as it were an instrument that represents many instruments. Thus it is to that animal (viz. man) which has the capability for acquiring the greatest number of crafts that Nature has given that instrument (viz. the hand) whose range of uses is the most extensive." 35 Cicero also considered the hand as nature's great gift to man: "We realize that it was by applying the hand of the artificer to the discoveries of thought and observations of the senses that all our conveniences were attained." 36 Lactantius describes the perfect form of the human hand in the service of man's reason and wisdom and part of the divine plan that distinguishes man from animal, endowing him with human dignity, in De opificio Dei. ${ }^{37}$ Ambrose in his Hexameron also praises the human hand for its aptitude for work, for doing great deeds, and also for its participation in the sacraments. ${ }^{38}$

Later Christian theologians and moralists also preached that manual labour not only remedies sloth; it can also redeem man from sin and lead the way to salvation. ${ }^{39}$ We may see the praise of the hand and of the sense of touch expressed in a late twelfth-century drawing depicting the course of human life, where the five senses form the rungs of the ladder which man must climb on his journey through life (fig. 3). ${ }^{40}$ Contrary to the traditional hierarchy, where sight takes the highest position, in this drawing touch is given the highest rank among man's senses and thus occupies the most pivotal position along man's journey toward salvation or perdition. The ladder takes the form of a Y. ${ }^{41}$ The two arms that split off from the stem curve in opposite directions, one upward towards heaven, the other downward towards hell; they are clearly symbolic of man's choice between virtue or vice. The bottom of the ladder rests within an arch-like structure, representing the domain of nature. Personified Nature expels from its mouth the figure of a naked man, who proceeds to climb the five, lower rungs of the path, labelled in ascending order: Vis[us], Auditus, Gustus, Odorato and Tactus. At the next rung, labelled Prudentia Imprudentia, the ladder splits into two, forming the branches of the $Y$. Above the naked man are two more figures: one pursues the path of virtue, the other, of vice. The former pushes off with his right foot securely wedged on the uppermost rung of the senses, inscribed Tactus, on his journey heavenward, where he must ascend rungs labelled with the four cardinal virtues. His next step on the ladder after Touch is to Prudence, then on to Temperance, Fortitude, and finally to Justice, where he is met by an angel who will escort him through the gate into Heaven. This man's arms and legs touch, lean, kneel, grasp, and pull at every rung on the ladder to salvation. He uses all parts of his appendages-arms, legs, knees - to reach his goal, but especially his hands, which tightly hold on to the rungs of Fortitude 
and Justice. ${ }^{42}$ The angel who ushers him through the gate of Heaven holds firmly on to his wrist with one hand and with the other gestures to the gate. One may wonder whether this crescendo of hands, which grasp, pull, and point, was intended to emphasize the importance of this appendage in man's salvation. It is also interesting to consider that it is the rung of Prudence/ Imprudence that splits upon completion of the series of the senses. Prudence, which was thought to include man's capacity to judge, rests upon man's ability to discriminate the information he receives from his external senses (of which touch in this drawing is shown to be, literally, the most pivotal); it is man's prudent—or imprudent-use of his senses, which determines whether he will continue his journey upward to the virtues or downward to the vices.

The simplicity of dress of the figure that chooses the path to Heaven suggests that he is also a simple man, a layman, perhaps even a labourer, who used his hands, i.e. his sense of touch, during his journey in the temporal world in order to bring himself closer to God. Unlike this man, who firmly grabs the rungs of the virtues, the other figure that now travels the path of vice is depicted as missing every step. His feet are encased in exaggeratedly pointed slippers, so that he cannot even make contact with the rungs of the vices that lead to his doom. The fingers of his hands are extended, as if paralyzed, and unable to stop his descent into the gate of Hell. A demon sits astride the man as though he were a horse and, pinning his victim's head in a yoke-like tool, pushes him further down the slope toward the gate of Hell. ${ }^{43}$ This man is dressed in a costume quite different from his virtuous fellow traveller. Aside from the absurdly long-pointed toes of his slippers, which reflect his wanton and luxurious lifestyle, we may also note the pattern of his dress, and the flared cuffs of his sleeves (certainly inappropriate garb for a man in need of the use of his hands), along with his uncovered head, revealing combed and parted hair. Clearly this man has indulged, not checked, his senses. His hands, the organs of touch, are useless to stop his fall into Hell, yet every other part of his body makes contact with the descending branch of vices. As he lived his life in an unrestrained manner, so he slides downward to his fate. We may note the text in the border, alongside the man being pushed into Hell by the demon, which warns of idleness and the carnal fantasies that have apparently been this man's ruin: "dvsede mentis vexant fantastmata carnis.”

What is depicted in this medieval drawing is not unlike the mythological fable of Hercules at the crossroads, except that here simple, mortal men must choose their path. ${ }^{44}$ Man's experience of the world, gained through his senses, enables him to deliberate and choose either the road to salvation (through the choice of the good and moral) or damnation (through the choice 
of the bad and immoral). For the men depicted along the journey of life, the rung of touch was the deciding factor in their prudent or imprudent use of the senses, and pivotal in whether they will follow the path of virtue or vice. Touch enables man to work or perform deeds that can bring him closer to God and salvation, but it also enables him to follow his libidinous and lustful tendencies, which lead him toward Hell.

In the view of the illustrator of this late twelfth-century drawing, the sense of touch occupies the critical position in influencing man's choice whether to grasp the rung of Prudence or to miss it and slip downward. In this context, touch is portrayed as the sense most necessary for discrimination and, consequently, for judgment. This illustrator, it would seem, presents a view of the sense of touch similar to that expressed by Thomas Aquinas, who posited that the sense of touch is the foundation of all the senses and close to the common sense. ${ }^{45}$ It has recently been suggested that this view of the sense of touch may explain the positioning of the sense of touch in the fourteenth-century wall painting at Longthorpe Tower depicting the wheel of the senses. ${ }^{46}$ The sense of touch is represented by a spider in its web, according to the passage in Thomas of Cantimpré's Liber de naturis rerum, which associates specific animals with each of the five senses. ${ }^{47}$ The spider in its web is positioned on the outside of the uppermost spoke of this fivespoke wheel, next to the head of the crowned, male figure that holds, and effectively, controls it. It has been suggested that this figure may symbolize Reason, which controls the senses; ${ }^{48}$ more recently, Gino Casagrande and Christopher Kleinhenz have proposed that the wheel itself and the crowned figure symbolize the Sensus communis with the spokes equivalent to the channels that lead the information gathered by the external senses to the sensus communis. ${ }^{49}$ The sense of touch, situated closest to the head of the figure (who looks directly at the spider in its web) would then be understood to be the sense by which the man would first judge the external world, hence its superior position. ${ }^{50}$ Perhaps touch's position on this wheel might also reflect the idea that it is this sense which enables man to pursue virtue through action.

The fifteenth-century Burgundian court chronicler and poet Olivier de la Marche (1425-1501), who served Charles the Bold, also presented a positive view of man's use of his sense of touch in the didactic poem "Les cinq sens," in which the feet and the hands are used in the performing of good deeds, "faictes pour aux povres donner" (do to give to the poor), and in serving both temporal and spiritual ends, "Pour mesnagier, tailler, coudre, filler, / Pour louer Dieu mains joinctes et prier” (for managing (a business or home), cutting, sewing, spinning, for praising God with joined hands and prayer). ${ }^{51}$ 
De la Marche recognized that good and evil may be revealed through the senses, but it was up to man to steer himself toward the good. Even Badius, in his pessimistic view of man's ability to control his impulsive use of touch, alerts his readers to the possibility of a better alternative.

While Badius and the illustrator pass judgment on the efficacy of the senses for the readers and viewers of the text and illustrations, the Nuremberg painter-engraver Georg Pencz offers a very different rendering of the senses about 40 years later, which allows the viewer to deliberate for himself the benefits and dangers of sensory perception. Pencz's engraving of touch presents an ambivalent image which encourages the viewer to negotiate the impulses of touch on his own and to choose whether to allow these urges to lead him to pursue the dangerous path toward lust or to find in them moral benefits.

Pencz conceives of the sense of touch as a nude, female personification busy at a ribbon loom (fig. 2). ${ }^{52}$ She sits upon a decorative, animal-footed stool, which recedes at an angle slightly to the left. Her lower body is covered by a piece of cloth that is draped over her legs and covers the seat and side of the stool. Facing to the right, she bends down to pass the threads on the ribbon loom, which rests atop a rectangular base at the right. Two completed ribbons are visible atop a table, placed below the window that punctuates the back wall of her shallow room. A spider's web stretches diagonally across the window from the lower left casement to the upper right, with the spider in the web's centre. The word TACTUS appears in the upper right space of the window and above it the artist's monogram. An inscription below the image reads: SED ARANEA TACTU.

Such a delicate and detailed small-scale image would have required an intimate viewing environment. ${ }^{53}$ The male viewer confronting the image of a female nude on such intimate terms would most certainly have appreciated both the pleasures and perils it might bestow. ${ }^{54}$ In a sense, Pencz associates the senses with notions of luxury and leisure: the viewing of these works could only have been undertaken by one who was wealthy enough to purchase the engravings, and who would have been able to allocate time from his (busy) day to enjoy them. Thus, only a wealthy man at leisure might have appreciated this print. Such a man, however, would be in danger of succumbing to the effects of this luxury and leisure. During his examination of this image, which he could have held in his hand and, due to its small size, close to his eye, the viewer might even have imagined touching the nude female figure.

Pencz, however, depicts the personification of touch in a rather modest pose. She is seated so that only her back, right arm, and a side-view of her 
stomach are visible. Her breasts are concealed behind her outstretched arm, which works the loom, and her head is lowered, as are her eyes as she attends to her work. Nordenfalk has proposed that Pencz gradually inclined the position of the head of each personification in the series as a compositional device meant to indicate the classical ranking of the senses. ${ }^{55}$ Sight lifts her eyes to the heavens (fig. 4), Hearing faces forward and confronts the viewer, Smell inclines her head toward the cornucopia she holds, Taste bends her head still further over a bowl of food, ${ }^{56}$ and the face of Touch is visible only in profile as she looks down at the ribbon loom, which she diligently manipulates with her hands.

Pencz has used another pictorial device to suggest an additional notion about the valuation of the senses: the noticeable difference between the loosely flowing locks of Sight and the neatly braided hair of Touch. ${ }^{57}$ Though hairstyle may be difficult to interpret as indicative of either the dissolute or restrained nature of each sense, it is worth considering that Sight's loose, falling tresses frame her breasts and thus call attention to them, whereas Touch's hair, tightly bound and braided, will not get in her way while she works the loom and is thus appropriate to her activity, and does not draw attention to the intimate parts of her anatomy. ${ }^{58}$

Pencz has placed the personification's busy hands at the middle of this print. Thus, while a close viewing might have aroused notions of the male viewing of the female nude, her working hands, the active instruments of touch, are literally and figuratively at the centre of the print. ${ }^{59}$ Pencz's depiction of touch might be considered a visual analog to Juvenal's description of the women of Latium, whom Badius had referenced in Stultiferae naves as exemplars of the virtuous behaviour that deters the dangerous pleasure of the senses. The hands of Pencz's personification of touch are engaged in a radically different pursuit than are the hands of the fools aboard the ship of touch in the illustration to Badius' treatise. The viewer holding the engraving might even consider to what purpose his hands are presently engaged.

Pencz's print coincides in time and place with the efforts of the Protestant reformers to disband local cloisters and nunneries in order to redefine women's role in society through the promotion of their contribution, through work in the home, to husband, family, and community. ${ }^{60}$ By mid-century, the voices of Protestant reformers intent upon creating a model woman who could be praised as a helpmate to her husband, vied with the moralizers who preached traditional misogynist attacks against women, vilifying them as whores, gadabouts, and gossips. Emblem-books defined the conduct and responsibilities of the virtuous woman by advocating that she remain sheltered and at home, ${ }^{61}$ and manuals of conduct taught the virtues of the good housewife. ${ }^{62}$ Broadsheets 
and print-series explained and extolled the role of women in the household. ${ }^{63}$ Women's mastery of spinning and needlecraft was almost always cited. ${ }^{64}$ Pencz's presentation of the female personification of touch as a solemn and modest woman, intensely fixated on her ribbon loom, may be a reflection of these sentiments. The difference between the directions of the gazes of Sight and Touch in Pencz's prints may even reflect what was considered to be the improper and proper gaze as censured or advocated in contemporary manuals of conduct. ${ }^{65}$ Sight looks upward and out of the window, effectively enabling her access beyond the safe confines of the enclosed space in which she sits, whereas Touch's gaze downward, ostensibly in order to concentrate on her work, confines her safely within the enclosed space in which she sits. Pencz's image of touch as a female personification busy at her loom might thus have been understood as the embodiment of the feminine virtue of industriousness, which deters sloth and lust. Nuremberg's religious reformers might have approved such notions of womanly virtues, despite the nudity.

The animal attribute of the spider in its web-which Pencz situates in the upper left corner of the window, behind the figure of touch-also referenced in the inscription, derives from the verse in Thomas of Cantimpré's Liber de naturis rerum, and suggests that the spider in its web functions as the animal exemplar of touch, that feels more keenly than man. ${ }^{66}$ Earlier we noted the spider's prime location in relation to the male figure in the wheel of the senses in the fourteenth-century wall painting in Longthorpe Tower. While we may conclude that Pencz is following an established literary and visual tradition in associating the spider with the sense of touch, ${ }^{67}$ the spider also carried additional emblematic meanings that would have been familiar to the learned audience that Pencz addresses. The spider in its web could have conjured for the viewer the association of the unwary lover who is caught in the snares of love. ${ }^{68}$ In this context, the spider's association with the dangerous effects of sensual touch is clear. But the spider could also have been understood as a visual complement to the depiction of the personification as a woman engaged in work at a loom.

As Judith Dundas notes in her analysis of the spider in emblem-books of the sixteenth and seventeenth centuries, the spider and its web were used to represent a wide variety of human conditions from sophism to human frailty, the power of evil, entrapment of the unwary, and even as a model of bad government. ${ }^{69}$ But the spider could also serve as a model for great craftsmanship. ${ }^{70}$ This association naturally draws upon the mythological tale of Arachne as told by Ovid in chapter 6 of the Metamorphoses. Minerva turns the weaver Arachne into a spider, not out of jealousy toward a better weaver than herself, but because the mortal dared to defy her. Though being 
turned into a spider was indeed a severe punishment, as Dundas points out, it enabled Arachne to continue to practise her craft.

The animal attribute of the spider could have been understood by Pencz's audience as an appropriate symbol both for its extremely sensitive touch, and also for the notion of its industriousness through its artful work. Although removed in time and place from Pencz's print, we may consider Veronese's analogous use of the spider's web in his illustration of the personification of Industry painted for the ceiling of the Sala del Collegio in the Doge's palace in Venice. In this work, executed between 1576 and 1578, the allegorical figure of industry holds up a spider's web and appears to marvel not only at the intricacy of the web's design and the fineness of its nearly-transparent thread but also at the industry of the tiny creature toiling diligently at its centre. ${ }^{71}$ In a similar way, Pencz's choice of the spider as the attribute of touch may have evoked not only the notions of the keenness and dangers of touch, but also the notion of industriousness, thus allowing for a positive moralizing interpretation of this attribute in relation to the personification.

The traditional association of touch with the dangers of lust that Badius had warned of at the beginning of the century was still current when Pencz designed this engraving. ${ }^{72}$ By presenting the personifications of the senses as nude women, Pencz adhered to the common notion of the senses as stimulating pleasure for the viewer. In the context of the sense of touch and of the lust that may be aroused by the tactile sense in particular, the spider may also function as emblematic of the dangerous consequences of sensual touch, and the net emblematic of the snare in which the unwary in love may be trapped. ${ }^{73}$ But Pencz ultimately presents an ambivalent image of this sense that is more than a simple illustration of its enactment. The viewer is faced with a variety of ways in which he might interpret the individual elements in the composition and thus may imagine a variety of interpretations and meanings for the tactile sense.

Pencz has placed Touch's hands visually and figuratively at the centre of the debate about the benefits and dangers of this sense. In referencing this sense's association with both lust and labour, he has created a moral dialogue. However, whereas at the beginning of the century, the illustrator of Badius' text on the sense of touch presented a condemnatory image, Pencz allows his learned and sophisticated viewers to use both their external and internal senses in order to judge the matter for themselves.

Tel Aviv University 


\section{Illustrations}

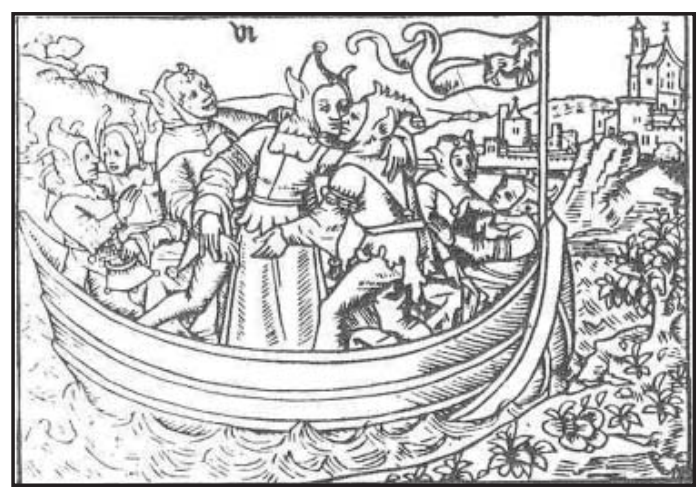

Fig. 1. "Ship of Foolish Touch” from Jodicus Badius Ascensius, Stultiferae naves (Paris 1500), Bibliothèque municipale de Lyon, Rés Inc. 1027, Crédit photographique Bibliothèque municipale de Lyon, Didier Nicole.

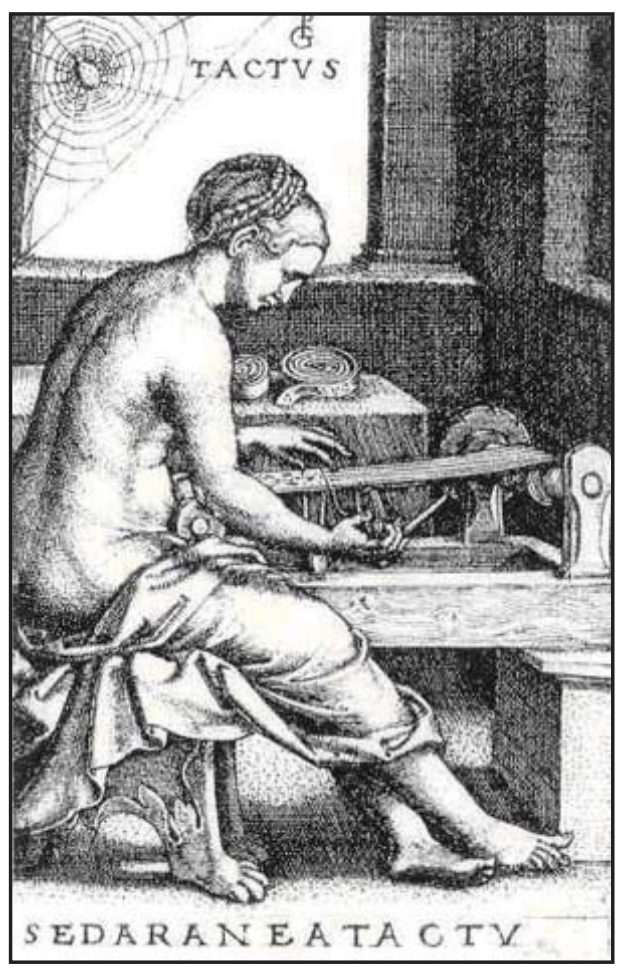

Fig. 2. Georg Pencz, “The Sense of Touch” from the series The Five Senses, Nuremberg, c. 1544, London, The British Museum: Copyright the Trustees of The British Museum. 
Sharon Assaf / The Ambivalence of the Sense of Touch in Early Modern Prints /91

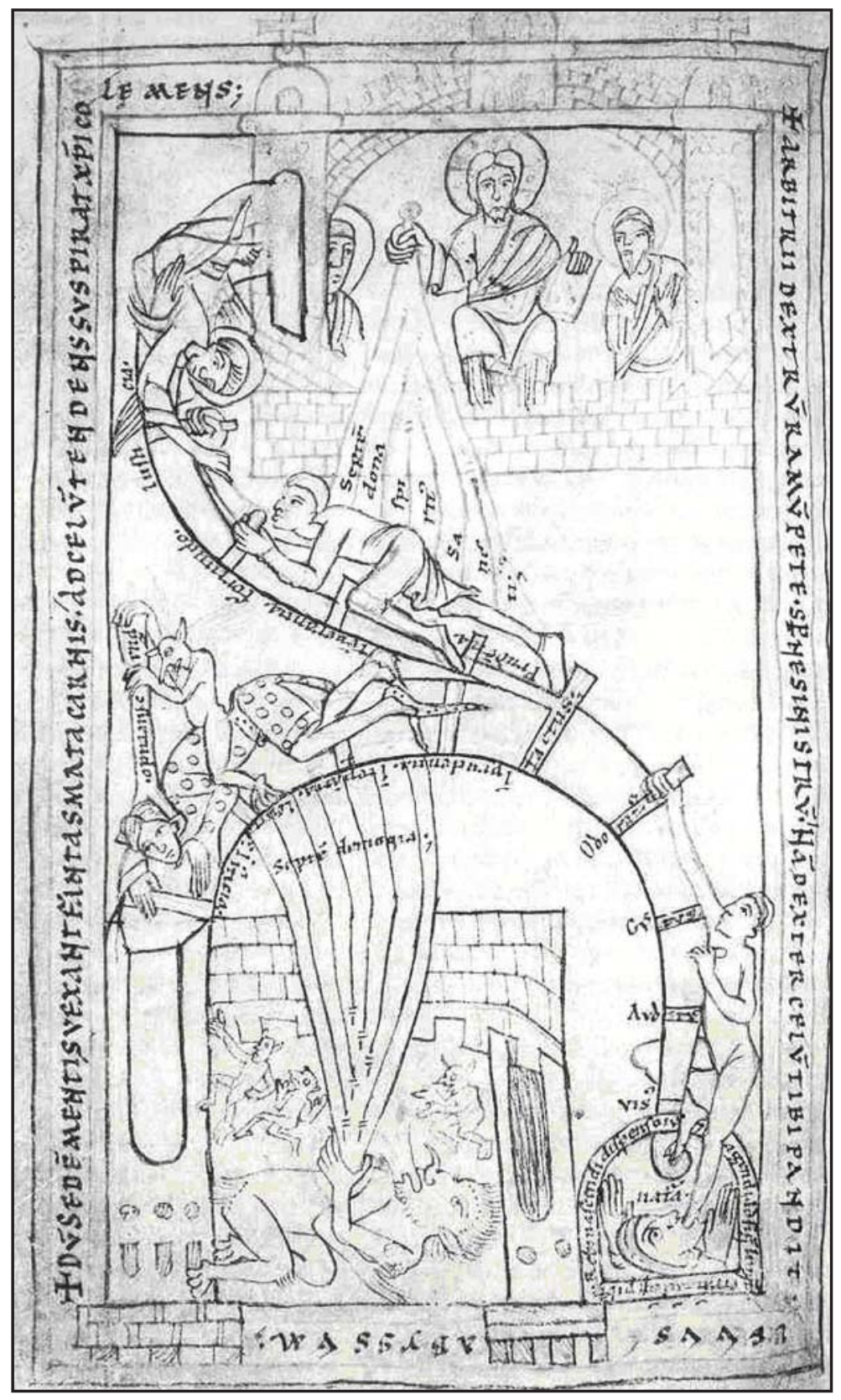

Fig. 3. The Two Courses of Human Life, second half of the $12^{\text {th }}$ century, Universitätsbibliothek Erlangen-Nürnberg, ms. 8, fol. 130v. 


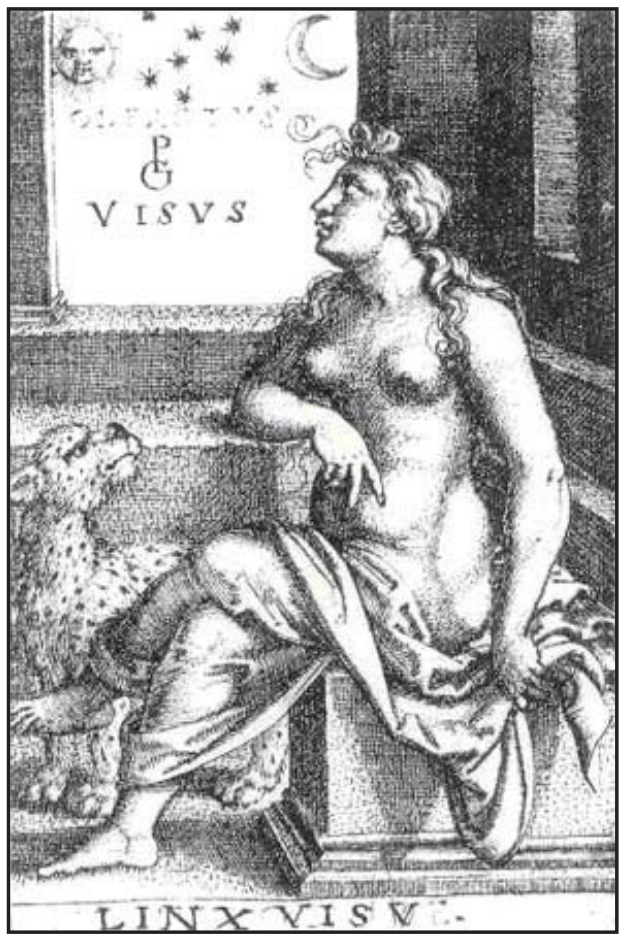

Fig. 4. Georg Pencz, "The Sense of Sight” from the series The Five Senses, Nuremberg, c. 1544, London, The British Museum: copyright the Trustees of the British Museum.

Notes

1. On the ambivalent reception of the sense of touch in early modern culture, see Elizabeth D. Harvey, "Introduction: The Sense of all Senses," in Sensible Flesh, On Touch in Early Modern Culture, ed. Elizabeth D. Harvey (Philadelphia: University of Pennsylvania Press, 2003), pp. 1-21.

2. The iconography of the senses refers to a specific format of image, whereby each sense imagined as a female personification is engaged in a particular action and is accompanied by a particular animal attribute. This iconographic formula took shape during the course of the sixteenth century, though certain elements, notably the animal attributes that accompany each sense, can be traced to literary traditions as far back as Pliny the Elder's Natural History. On this, see Louise Vinge, The Five Senses, Studies in a Literary Tradition (Lund: Royal Society of Letters, 1975), pp. 38-39 and 47-53. Jodicus Badius Ascensius' Stultiferae naves, published in 1500, and Georg Pencz's five-part series of copper-plate engravings, dated to 1544, begin a vogue for serial engravings of the five senses, which remained extremely popular throughout the second half of the sixteenth century. In 1561 the Antwerp artist Frans Floris created a five-part series that was engraved by Cornelis Cort, which became a template for future renderings of this theme. 
Numerous variations on this iconographic format were produced by leading Flemish and Dutch artists throughout the second half of the sixteenth century. For a general survey of the imagery see Carl Nordenfalk, "Five Senses in Late Medieval and Renaissance Art," Journal of the Warburg and Courtauld Institutes 48 (1985), pp. 1-21; Nordenfalk, "The Five Senses in Flemish Art before 1600,” Netherlandish Mannerism, ed. Görel CavalliBjorkman (Stockholm: Nationalmuseum, 1985), pp. 135-53. Nordenfalk describes rather than analyzes the evolution of the iconography. For analysis of the visual development of the iconography of the senses in the sixteenth century and how the iconography relates to conceptual, intellectual, and ethical questions posed by ancient and medieval philosophers and theologians, as well as addressing more contemporary texts and social and cultural issues, see Sharon Assaf, "Visualizing the Senses: Printed Images of the Five Senses in Northern Europe in the Sixteenth Century" (Ph.D. diss., Tel Aviv University, 2004).

3. Harvey, p. 1. On the association of the sense of touch with the vices of lust and lechery, see Nordenfalk, “The Five Senses in Flemish Art,” pp. 135-53; Bernard Rosiers, "Waarschuwing tegen wellust, De tastzin in Frans Floris' prentenreeks de vijf zintuigen,” Kunstlicht 4 (1988), pp. 23-26; Sander Gilman, “Touch, Sexuality and Disease,” Medicine and the Five Senses, ed. W.F. Bynum and Roy Porter (Cambridge: Cambridge University Press, 1993), pp. 198-226.

4. Originally intended as a supplement to a Latin edition of Sebastian Brant's Das Narrenschiff (Basel, 1494), Jodicus Badius Ascensius’ book, Stulturus naves sensus animosques trahentes Mortis in exitium, divided into six chapters, the first devoted to the Ship of Eve and the following five to each of the senses, combined text and verse along with six woodcuts. It was printed by Thielmann Kerver for Angelbert and Geoffrey de Marnef (February 18, 1500). For a reproduction of Badius’ original text see Charles Béné et al., La Nef des Folles. Stultiferae naves de Josse Bade, Reproduction de l'édition princeps d'Angelbert de Marnef (Paris, 1500) (Grenoble: Publications de l'Université de langues et lettres de Grenoble, 1979); see also Nordenfalk, "Five Senses in Late Medieval and Renaissance Art,” pp. 11-15.

5. David Landau, Catalogo completo dell'opera grafica di Georg Pencz (Milan: Salamon e Agustoni, 1978), p. 64 and pp. 135-136; Nordenfalk, "Five Senses in Late Medieval and Renaissance Art,” pp. 19-20.

6. With regard to the Stultiferae naves, the working relationship among Badius, the anonymous illustrator, and the publisher remains unclear. Did the illustrator work closely with the author, was he directed by the publisher, or was he allowed a more autonomous role? The illustrator clearly transmits Badius' overall message of the dangers that befall those who succumb to the pleasures of the senses, but his images also include notions not mentioned explicitly in Badius' text, suggesting that he was drawing inspiration from additional sources, both visual and verbal, particularly from proverbial expressions. The viewers of the images thus have points of reference from which to interpret the woodcuts besides the text of the treatise, suggesting a particular sophistication on the part of the audience, especially the women who might not have been able to read the Latin text.

7. The hand as the organ of touch, and its role in pursuit of virtue or vice, remains constant throughout the sixteenth century iconographic tradition of this sense as may be seen particularly in the prints after designs by Frans Floris, Maarten de Vos, and Hendrick Goltzius. See Assaf. A number of recent studies have drawn attention to the varied pow- 
94/ Renaissance and Reformation / Renaissance et Réforme

ers of the hand in early modern culture. Of particular interest are Katherine Rowe, "God's handy worke," The Body in Parts, ed. Carla Mazzio and David Hillman (New York: Routledge, 1997), pp. 285-312; Marjorie O’Rourke Boyle, Senses of Touch, Human Dignity to Deformity from Michelangelo to Calvin (Leiden: Brill, 1998); Claire Richter Sherman, Writing on Hands, Memory and Knowledge in Early Modern Europe, exh. cat. (Carlisle, PA: Dickenson College, 2000).

8. See Charles Béné, "Introduction,” La Nef des Folles. Stultiferae naves de Josse Bade, Reproduction de l'édition princeps d'Angelbert de Marnef (Paris, 1500), pp. 3-21; Yona Pinson, "La Nef des Folles (The Ship of Female-Fools)," in The Fools' Journey. A Myth of Obsession in Northern Renaissance Art (forthcoming), looks at Jehan Drouyn's translation into French of Badius's text and Drouyn's supplementary chapters which expand the misogynist message. Anna Olga Duhl is working on a critical edition of Drouyn's Middle French text.

9. The sixteenth-century Spanish Humanist Juan Luis Vives's discussion of the senses in a number of his works is another important point of reference for interpreting the iconographic tradition of the senses that was taking shape at the time. See Assaf.

10. Badius, pp. 55-56 and 112. The English translations of Badius are my own. For Badius' quotes from Ancient sources, I have used the Loeb classics series.

11. "Jodicus Badii Asensii a stultifera navi ad quam per carnis illecebras appellimur avocation,” as in Badius, pp. 57, 114.

12. The copper-plate engraving was a more expensive image to produce than a woodcut and therefore suggests that they were intended for a particular audience able to purchase the more costly images and to appreciate the technical aspects of this type of print. The Latin subscripts suggest as well the erudition of the audience that would have been able to negotiate the succinct text as well as interpret the relationship between text and image. On audience reception for these images, see Assaf, pp. 10-11.

13. Assaf, pp. 15-19.

14. Nordenfalk, “Five Senses in Late Medieval and Renaissance Art,” p. 20.

15. Nordenfalk, “The Five Senses in Flemish Art before 1600,” pp. 137-38; Rosiers, pp. 236; Ilja Veldman, “Goltzius’ Zintuigen, Seizonen, Elementen, Planeten en Vier tijden van de dag: van allegorie naar genre-voorstelling,” Nederlands Kunsthistorisk Jaarboek 41/42 (1991-1992), pp. 307-12; on the dangers of sight and the seductive power of woman's beauty, see Eric Jan Sluijter, "Venus, Visus and Pictura," Seductress of Sight, Studies in Dutch Art of the Golden Age, trans. Jennifer Kilian and Katy Kist (Zwolle: Waanders, 2000), pp. 87-159.

16. As noted above, Badius makes this observation in the introductory lines to the chapter on the sense of touch, "the fifth and last sense is the touch, common to all animate beings which use the entire body and therefore is the more dangerous because one derives from it great pleasure” (Badius, pp. 54, 111).

17. Xenophon, Memorabilia, II.1.21-33. Xenophon's description of the seductress of pleasure stresses her immodest dress, her upturned gaze, and her self-inspection: "open eyed was she; and dressed so as to disclose all her charms. Now she eyed herself; anon looked whether any noticed her; and often stole a glance at her own shadow.” See also Vinge, p. 21. 
18. Xenophon, II.1.24. Vinge, p. 21, and n. 22.

19. Vinge, pp. 22-4. Philo, trans. F. H. Colson and G. H. Whitaker, 11 volumes, (Cambridge, MA.: Harvard University Press, 1950), vol. 2, pp. 105-21. Philo uses the allegory in order to explain the reverse of the birth order of the brothers Cain and Abel in verse 2 of Genesis 4, where the younger brother Abel is mentioned before his elder brother Cain. Philo suggests that vice may be older in point of time, but virtue is the more worthy and therefore is first. See, Philo, vol. 2, pp. 88-89.

20. Philo, vol. 2, p. 89, and pp. 121-7.

21. Philo, vol. 2, p. 109. Note that here taste precedes smell in the ranking of the senses, giving smell a greater role in stimulating sensual pleasure.

22. Philo, vol. 2, p. 109.

23. Philo, vol. 2, p. 121.

24. Divinae Institutiones, 6.23: “De Tactus Voluptate Et Libidine, Atque de Matrimonio Et Continentia.” See also Vinge, pp. 36-7.

25. Particularly Book X, Chapter 30; Vinge, pp. 39-46.

26. Badius, pp. 55-56, 112.

27. For the goat as the symbol of Luxuria, see Guy de Tervarent, Attributs et Symboles dans L'Art Profane (Geneva: Droz, 1997), p. 72. See also Andreas Alciatus, The Latin Emblems, Indexes and Lists, 2 vols., ed. Peter M. Daly (Toronto: University of Toronto Press, 1985), vol.1, emblem 72, “Luxuria” (“wantonness”).

28. For a similar theme in a print by Lucas van Leyden, see Larry Silver, "Fools and Women: Profane Subjects by Lucas van Leyden,” Print Collectors Newsletter 14/4 (1983), p. 130 and figure on p. 131.

29. Badius, pp. 57-58, 114-115.

30. Brian Vickers, "Leisure and Idleness in the Renaissance: The Ambivalence of Otium," Renaissance Studies 4/1 (1990) (hereafter Vickers a, "Leisure and Idleness”), p. 5; Brian Vickers, "Leisure and Idleness in the Renaissance: The Ambivalence of Otium," Renaissance Studies 4/2 (1990) (hereafter Vickers b, "Leisure and Idleness”), p. 111.

31. Ovid, Remedia Amoris, "Tam Venus otia amat; qui finem quaeris amoris,/ Cedit amor rebus: res age, tutus eris" (1l. 143-4, "so Venus loves Leisure: if you want an end to your loving, keep busy - / Love gives way to business - and you'll be safe,” as in Vickers a, "Leisure and Idleness,” p. 23.

32. Vickers b, “Leisure and Idleness,” p. 108.

33. Ilja Veldman, "Images of Labour and Diligence in Sixteenth Century Netherlandish Prints: The Work Ethic Rooted in Civic Morality or Protestantism?” Simiolus 21/4 (1992), pp. 241-42 and fig. 19.

34. Aristotle, De anima, 424b. Earlier in De anima (414a5) Aristotle said: "The phrase 'that whereby we live and perceive' has two senses, as has 'that whereby we know' (in the one sense we mean knowledge and in the other the soul; for we say we know by each of these)."

35. Aristotle, De partibus animalium, 4.10.687. Cicero also praises the hand in De natura deorum 2.60.150: "Then what clever servants for a great variety of arts are the hands which nature has bestowed on man!” 
36. Cicero, De natura deorum 2.60.150-52

37. Lactantius, De opificio Dei, 3.17, 20; 5.11-13; 10.21-25; Boyle, p. 49, and n. 241.

38. Ambrose, Hexameron 6.9.69; Boyle, p. 72.

39. Vickers b, "Leisure and Idleness,” p. 110; Veldman, "Images of Labor and Diligence," p. 235.

40. Chu-tsing Li, The Five Senses in Art: An Analysis of its Development in Northern Art (Ph.D. diss., State University of Iowa 1955), pp. 17-19; Carl Nordenfalk, "Les Cinq Sens dans l'art du Moyen-Âge,” Revue de l'art 34 (1976), pp. 18-19; Lubomir Konečny, "I Cinque Sensi da Aristotele a Constantin Brancusi,” in Immagini del Sentire, I cinque sensei nell'arte, exh. cat. (Cremona, 1996), p. 27.

41. On the $Y$ as indicative of human choice see Yona Pinson, "Hieronymus Bosch-Homo Viator at a Crossroads,” Artibus et Historiae 52 (2005), p. 57 and n. 7.

42. Aristotle (De anima 421 a 19-20) argued that in delicacy of touch man is far superior to other living beings and that man's superior intelligence is due to his superior tactile discrimination, an idea taken up by St Thomas Aquinas in his commentary on Aristotle. See David Summers, The Judgment of Sense (Cambridge: Cambridge University Press, 1987), pp. 103-4.

43. The gate, walls, and inhabitants of Hell are depicted upside down, perhaps literally visualizing the inverted world of vice and evil.

44. Konečny (p. 27, n. 30) notes the comparison of this image with the Hercules fable.

45. Gino Casagrande and Christopher Kleinhenz, "Literary and Philosophical Perspectives on the Wheel of the Five Senses in Longthorpe Tower,” Traditio 41 (1985), p. 318.

46. Casagrande and Kleinhenz; Nordenfalk, “Les Cinq Sens dans l'art du Moyen-Âge,” pp. 24-5; Vinge, pp. 48-53; E. Clive-Rouse and A. Baker, “The Wall Paintings at Longthorpe Tower near Peterborough, Northants,” Archaeologia 96 (1955), pp. 1-58.

47. Vinge, pp. 50-3.

48. Vinge, p. 53 and n. 17.

49. Casagrande and Kleinhenz, pp. 322-7.

50. Casagrande and Kleinhenz, p. 326.

51. As in Vinge, pp. 61-62 and n. 30, from Henri Stein, Olivier de la Marche, historien, poète et diplomate bourguignon (Bruxelles, Paris: A. Picard, 1888), p. 227.

52. Pencz's figure operates an inkle loom. It is a simple machine, fast to operate, which can make belts and straps that can be combined with hand weavings.

53. The dimensions of this print are $77 \times 51 \mathrm{~mm}$. On how the size of the print may be related to how it was viewed, see Assaf, Introduction, pp. 10-11.

54. On sixteenth-century notions regarding sensual arousal through the viewing of images see David Freedberg, The Power of Images, Studies in the History and Theory of Response (Chicago and London: University of Chicago Press, 1989), pp. 317-44.

55. Nordenfalk, “Five Senses in Late Medieval and Renaissance Art,” pp. 19-20.

56. For other images, see Nordenfalk, "Five Senses in Late Medieval and Renaissance Art," figs. $8 \mathrm{~b}-\mathrm{d}$. 
57. The hair of the senses of Sight, Hearing, and Smell are done in à l'antique fashion featuring a top-knot, whereas the figures of Taste and Touch have more contemporary hairstyles, made of braided hair that is wrapped around the back of the head and pulled away from the face. Pencz had used similar hairstyles in his depictions of the female personifications of Justice and Charity from an engraved series of the Christian Virtues.

58. James Hall, however, suggests that in the Renaissance the hair of a courtesan or of the personification of profane love is generally braided. The viewer may, on the one hand, find Touch's hair appropriately arranged, given her work at the loom; on the other hand, he may have associated this style with women of dubious character. Thus her appearance in this print may have been purposefully ambiguous. See Hall, Dictionary of Subjects and Symbols in Art (New York: Harper and Row, 1974 [rev. ed. 1979]), p. 144.

59. We may compare Touch's hands with the hand of Sight in Pencz's print that is pointing to and caressing the flesh between her stomach and genitals, and that is literally at the centre of that print See Assaf, pp. 38-40.

60. See Steven Ozment, When Fathers Ruled: Family Life in Reformation Europe, (Cambridge: Cambridge University Press, 1983), chap. 2, "Husbands and Wives"; Lyndal Roper, The Holy Household: Women and Morals in Reformation Augsburg, (Oxford: Oxford University Press, 1989), pp. 40-9; Olwen Hufton, The Prospect Before Her: A History of Women in Western Europe, 1500-1800, Vol. 1. (New York: Vintage Books, 1998), pp. 400-23.

61. As in Alciatus, The Latin Emblems, emblem 196.

62. Such as Juan Luis Vives's De institutione feminae Christianae which he wrote in 1523 while in England and dedicated to Princess Mary, daughter of Henry VIII and Catherine of Aragon. See Juan Luis Vives, The Education of a Christian Woman, ed. and trans. Charles Fantazzi, (Chicago and London: University of Chicago Press, 2000); Boyle, pp. 150-51. For other examples of contemporary manuals of conduct for women see Wayne E. Franits, Paragons of Virtue, Women and Domesticity in Seventeenth Century Dutch Art (Cambridge: Cambridge University Press, 1993), pp. 64-7.

63. Ilja Veldman, "Lessons for Ladies: A Selection of Sixteenth and Seventeenth Century Dutch Prints,” Simiolus 16 (1986), figs. 1-11.

64. Boyle, pp. 150-52; Franits, pp. 22-9.

65. Carla Casagrande "The Protected Woman," in Silences of the Middle Ages, Vol. 2. A History of Women in the West, ed. C. Klapisch Zauber, general ed. Georges Duby and Michelle Perrot (Cambridge, MA and London: Belknap Press of Harvard University Press, 1994), pp. 84-6. Casagrande cites the fifteenth-century humanist and moralist Francesco Barbaro who ridiculed women who sewed at the window: "Those who sit at the window to sew often end up sewing their hands instead of their clothes" (p. 86). This notion of the woman at the window offers an interesting analogy to Pencz's placement of the personification of touch working her loom near an open window. On the significance of the window as backdrop to Pencz's entire series in relation to the literary topos of the senses as the windows to the soul, see Assaf, p. 140 and n. 28. For the meaning of the object of Sight's gaze in Pencz's print, see Assaf, pp. 25-34.

66. On the animal attributes of the senses see Vinge, pp. 47-58.

67. Nordenfalk ,“Five Senses in Late Medieval and Renaissance Art,” p. 20. 
98/ Renaissance and Reformation / Renaissance et Réforme

68. Judith Dundas “Arachne’s Web: Emblem into Art,” Emblematica 2/1 (1987), p. 109.

69. Dundas, pp. 109-10.

70. Dundas, pp. 112-14.

71. Dundas, p. 116, and p. 136, fig. 14.

72. Badius' treatise and the expanded French vernacular translation by Jehan Drouyn were printed twelve times over the course of the sixteenth century, with the last publication dated to 1595. See Béné, “Introduction,” Stultiferae naves, p. 3.

73. Dundas, p. 109. 